\title{
Microwave-promoted three-component Hantzsch synthesis of acridinediones under green conditions
}

\author{
Behzad Zeynizadeh* and Masumeh Gilanizadeh
}

Faculty of Chemistry, Urmia University, Urmia 5756151818, Iran

\begin{tabular}{l} 
C H R O N I C L E \\
\hline Article history: \\
Received January 2, 2017 \\
Received in revised form \\
March 1, 2017 \\
Accepted April 21, 2017 \\
Available online \\
July 27, 2019 \\
\hline Keywords: \\
Acridinediones \\
Arylaldehydes \\
Dimedone \\
Hantzsch synthesis \\
Microwave \\
\hline
\end{tabular}

\begin{abstract}
A B S T R A C T
In this study, a green and practical approach towards Hantzsch dihydropyridine synthesis of acridine-1,8-diones is introduced. Via the mentioned protocol, the one-pot condensation reaction of structurally diverse aromatic aldehydes, dimedone and NH4OAc was promoted by microwave radiation at solvent and catalyst-free conditions. Consequently, acridinedione products were produced in $81-97 \%$ yields within 3-8 min. The current protocol represents the prominent advantages in terms of the using a simple synthetic procedure, short reaction times, mild reaction conditions, high yield of the products as well as omission of hazardous and costeffective organic solvents/reagents.
\end{abstract}

(C) 2020 Growing Science Ltd. All rights reserved.

\section{Introduction}

Multi-component reactions (MCRs) have been widely utilized as an efficient synthetic protocol towards preparation of numerous organic and pharmacological materials. ${ }^{1}$ This method bring an economical and environmental-friendly approach via the one-pot condensation reaction of three or more components in a onestep to produce new compounds containing the starting materials in their skeletal arrangement. ${ }^{2}$

Acridinediones are one of the important class of nitrogen heterocyclic compounds involving the ring of 1,4dihydropyridine (1,4-DHP). These materials are considered as effective pharmaceutical agents and active intermediates in organic and medical chemistry. ${ }^{3,4}$ Furthermore, acridinedione derivatives have a wide range of biological activities such as anti-microbial, ${ }^{5-7}$ anti-fungal, ${ }^{8}$ anti-bacterial, ${ }^{9}$ anti-tumor, ${ }^{10}$ anti-cancer, ${ }^{11}$ antiglaucoma, ${ }^{12}$ anti-malarial, ${ }^{13-15}$ DNA binding properties ${ }^{16}$ and inhibitors of carbonic anhydrase ${ }^{17} 1,4$-DHPs are also utilized as electroluminescence materials and can be used in laser dyes because of their strong fluorescent activities. ${ }^{18,19}$ In this context, the multi-component Hantzsch synthesis of 1,4-dihydropyridines has been widely utilized as an efficient synthetic procedure for preparation of acridinediones through the one-pot condensation reaction of aldehydes, $\beta$-diketones and various nitrogen containing compounds such as urea, methyl amine, ammonium acetate, aniline or other appropriately primary amines. ${ }^{20,21}$ Because of the great conveniences of acridinediones, therefore, the immense interest has been devoted to the synthesis of these materials using

* Corresponding author.

E-mail address: bzeynizadeh@gmail.com (B. Zeynizadeh)

(C) 2020 Growing Science Ltd. All rights reserved.

doi: $10.5267 /$ j.ccl.2019.8.001 
heterogeneous or homogeneous catalyst systems. ${ }^{22-41}$ Although most of the reported methods exhibit the useful synthetic advantages, however they generally suffer from shortcomings in terms of using expensive and hazardous solvents/reagents, the prolonged reaction times, undesirable yields, harsh reaction conditions and tedious work-up procedures. Therefore, the development and introduction of a green and practical approach which eliminate utilizing cost-effective solvents/catalysts from the medium of reactions, based on the principles of green chemistry, is more demanded.

Nowadays, the useful utility of microwave radiation in organic synthesis has attracted the considerable interest of numerous scientists. Via this synthetic method, the amazing acceleration, selectivity (chemo-, regioand stereo-) and high yield as well as the purity of products under mild conditions are accessible. The influence of microwave radiation is derived from the combination of thermal effect (arising from the heating, superheating or hot spots) and the selective absorption of radiation by polar substances. This type of promotion is not usually accessible by classical heating and the polarizing radiation involving non-thermal effects. ${ }^{42-44}$ In this area, the existence of numerous reports in literature shows the importance of microwave radiation towards synthesis of various materials ${ }^{45-52}$ as well as 1,4-dihydropyridines ${ }^{53-57}$ in dry or solution media.

Aligned to the outlined strategies and continuation of our research program towards synthesis of acridinediones using the magnetic layered double hydroxide ${ }^{58}$ herein, we wish to report a simple and efficient procedure for the titled transformation under solvent and catalyst-free conditions. The reactions were carried out through the three-component condensation reaction of aromatic aldehydes, dimedone and $\mathrm{NH}_{4} \mathrm{OAc}$ under microwave radiation to afford the products in high to excellent yields (Figure 1).

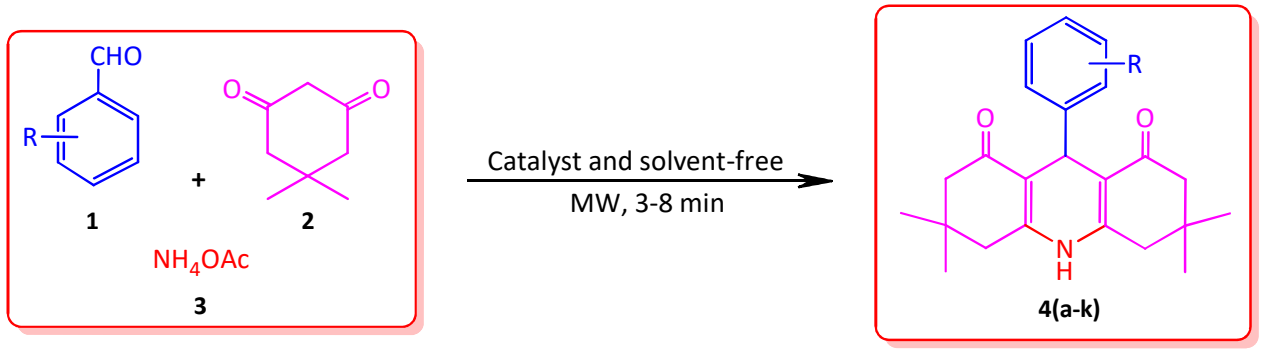

Figure 1. Synthesis of acridinediones promoted by microwave radiation

\section{Results and Discussion}

The study was started by performing the Hantzsch synthesis of 3,3,6,6-tetramethyl-9-phenyl-3,4,6,7,9,10hexahydro-acridine-1,8(2H,5H)-dione $\mathbf{4 a}$ through the three-component reaction of benzaldehyde $(\mathbf{1}, 1 \mathrm{mmol})$, dimedone $(\mathbf{2}, 2 \mathrm{mmol})$, and ammonium acetate $(\mathbf{3}, 1.5 \mathrm{mmol})$ under various conditions involving the change of reaction-solvent, temperature as well as radiation of microwave at 500 and $700 \mathrm{~W}$ power energy. The results of these investigations were summarized in Table 1. The table shows that progress of the titled reaction inside the solvents $\left(\mathrm{H}_{2} \mathrm{O}, \mathrm{MeOH}, \mathrm{EtOH}\right.$ and THF) even at reflux was not noteworthy. Further examinations resulted that the influence of microwave radiation for synthesis of acridinedione 4a was more satisfactory. Examining of the power amplitude for radiation of microwave resulted that using the energy of $700 \mathrm{~W}$ was the requirement for completion of the condensation reaction within $5 \mathrm{~min}$. Therefore, the condition mentioned in entry 8 (Table 1) was selected as the optimum reaction conditions.

Table 1. Optimization experiments for synthesis of acridinedione $\mathbf{4 a}^{*}$

\begin{tabular}{cccccc}
\hline Entry & Solvent $(2 \mathrm{~mL})$ & Temperature $\left({ }^{\circ} \mathrm{C}\right)$ & Microwave (Watt) & $\begin{array}{c}\text { Time } \\
(\mathrm{min})\end{array}$ & $\begin{array}{c}\text { Conversion } \\
(\%)\end{array}$ \\
\hline 1 & $\mathrm{H}_{2} \mathrm{O}$ & Reflux & - & 240 & 0 \\
2 & $\mathrm{MeOH}$ & Reflux & - & 120 & 5 \\
3 & $\mathrm{EtOH}$ & Reflux & - & 120 & 5 \\
4 & $\mathrm{THF}$ & Reflux & - & 100 & 8 \\
5 & Solvent-free & r.t. & - & 120 & 0 \\
6 & Solvent-free & - & 500 & 120 & 15 \\
7 & Solvent-free & - & 700 & 10 & 95 \\
8 & Solvent-free & - & 5 & 100 \\
\hline
\end{tabular}

${ }^{*}$ All reactions were carried out with the molar ratio of 1:2:1.5 for benzaldehyde, dimedone and $\mathrm{NH}_{4} \mathrm{OAc}$, respectively. 
The utility of catalyst and solvent-free synthesis of acridinedione $\mathbf{4 a}$ by microwave radiation was further investigated by the three-component condensation reaction of structurally diverse aromatic aldehydes, dimedone and ammonium acetate at the optimized reaction conditions. The results of these investigations were illustrated in Table 2. Investigation of the results exhibited that all reactions were carried out successfully with 5-8 min to afford the products in high to excellent yields. Moreover, it is notable that the influence of electron-withdrawing and releasing functionalities of the aromatic rings on the rate of condensation reactions was negligible.

Table 2. Microwave-assisted synthesis of acridinediones under catalyst and solvent-free conditions ${ }^{\mathrm{a}}$

\begin{tabular}{|c|c|c|c|c|c|c|c|c|}
\hline \multirow{2}{*}{ Entry } & \multirow{2}{*}{ Substrate } & \multirow{2}{*}{ Product } & & \multirow{2}{*}{$\begin{array}{l}\text { Time } \\
\text { (min) }\end{array}$} & \multirow{2}{*}{$\begin{array}{l}\text { Yield } \\
(\%)^{\mathrm{b}}\end{array}$} & \multicolumn{3}{|c|}{$\operatorname{Mp}\left({ }^{\circ} \mathrm{C}\right)$} \\
\hline & & & & & & Found & Reported & Ref. \\
\hline 1 & & & $4 a$ & 5 & 95 & $273-275$ & $277-278$ & 40 \\
\hline 2 & & & $4 b$ & 7 & 86 & $>300$ & $>300$ & 36 \\
\hline 3 & & & $4 c$ & 3 & 81 & $278-280$ & 299-301 & 37 \\
\hline 4 & & & $4 d$ & 4 & 97 & $>300$ & $>300$ & 41 \\
\hline 5 & $-c$ & & $4 e$ & 6 & 91 & 298-300 & $295-297$ & 38 \\
\hline 6 & & & $4 f$ & 8 & 91 & 298-300 & $290-292$ & 36 \\
\hline
\end{tabular}


7<smiles>O=Cc1ccc([N+](=O)[O-])cc1</smiles>

8<smiles>O=Cc1cccc([N+](=O)[O-])c1</smiles>

9<smiles>O=Cc1ccc(Cl)c([N+](=O)[O-])c1</smiles>

10<smiles>O=Cc1ccc(Cl)cc1Cl</smiles>

11

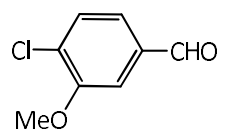<smiles>CC1(C)CC(=O)C2=C(C1)NC1=C(C(=O)CC(C)(C)C1)C2c1ccc([N+](=O)[O-])cc1</smiles>

$4 g$ 3 81 271-273

$4 h$<smiles>C=C(C)C1C2=C(CC(C)(C)CC2=O)NC2=C1C(=O)CC(C)(C)C2</smiles>
5

91

295-297

298-300 36

$4 i$ 6 86 275-277<smiles>C=CC1C2=C(CC(C)(C)CC2=O)NC2=C1C(=O)CC(C)(C)C2</smiles><smiles>C1CCC1</smiles><smiles>CC1(C)CC(=O)C2=C(C1)NC1=C(C(=O)CC(C)(C)C1)C2c1ccc(Cl)cc1</smiles>

$4 j$ 8 91 $>300$

$4 k$ 6 81 297-299 300

\footnotetext{
${ }^{a}$ All reactions were carried out with aromatic aldehyde $(1 \mathrm{mmol})$, dimedone $(2 \mathrm{mmol})$ and $\mathrm{NH}_{4} \mathrm{OAc}(1.5 \mathrm{mmol})$ under solvent and catalyst free conditions using microwave irradiation $(700 \mathrm{~W}) .{ }^{\mathrm{b}}$ Yields refer to isolated pure products.
}

Suitability of this synthetic protocol was also highlighted by comparison of the obtained result for synthesis of acridinedione 4a with current protocol and the previously reported systems (Table 3). A case study shows that in terms of high yield, short reaction time, the elimination for using hazardous and expensive organic solvents/promoters, the present system shows the prominent advantages in comparison to the previously reported works.

Although the exact mechanism of this synthetic protocol is not clear, however, a depicted mechanism (Fig. 2) explains the role of microwave radiation and condensation pathways of the reactants leading to the synthesis of acridinedione materials. The mechanism shows that through the Knoevenagel condensation of activated arylaldehyde (I) with dimedone, the benzylidene diketone (II) was produced. At the next, the Michael reaction of second molecule of dimedone with the activated benzylidene diketone (III) affords the bisdimedone intermediate (IV). Finally through the intramolecular reaction of the prepared imino product $(\mathbf{V})$ and ring closing step, the final acridinedione (VI) was produced. 
Table 3. Comparison of the synthesis of acridinedione 4a with different protocols

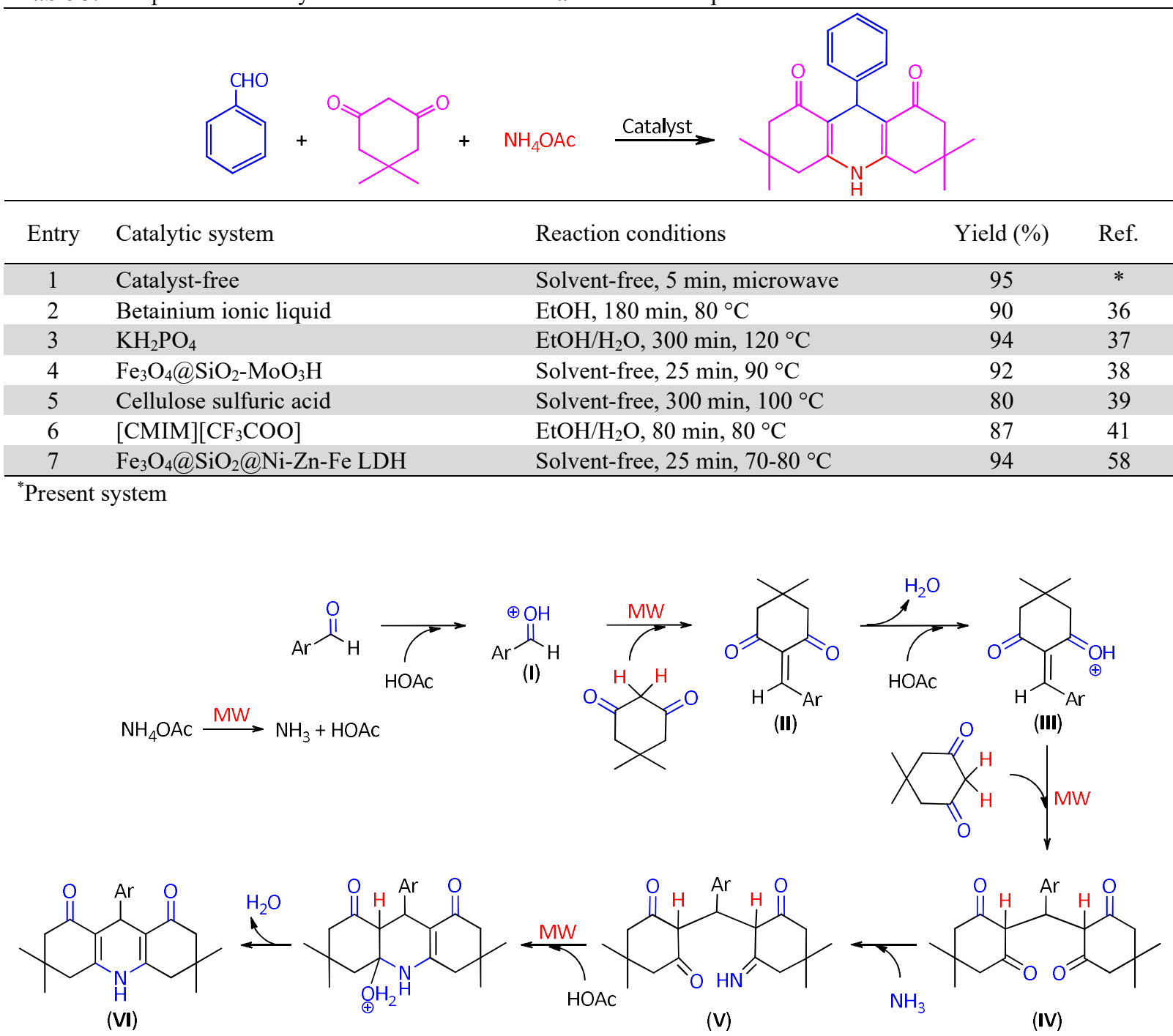

Fig. 2. A plausible mechanism for microwave-assisted synthesis of acridinediones

\section{Experimental}

\subsection{Materials and methods}

All chemicals and solvents were purchased from commercial sources and they were used without further purification. ${ }^{1} \mathrm{H},{ }^{13} \mathrm{C}$ NMR and FT-IR spectra were recorded on Bruker Avance $(300 \mathrm{MHz})$ and Thermo Nicolet Nexus 670 instruments, respectively. The products were characterized by their spectra and compared with the reported data in the literature. All yields refer to isolated pure products. Thin layer chromatography (TLC) was used for the purity determination of substrates, products and reaction monitoring over silica gel $60 \mathrm{~F}_{254}$ aluminum sheet. Melting points were measured in open capillary tubes with Electrothermal 9100 melting point apparatus and were uncorrected. A domestic microwave oven was used for irradiation of microwave.

\subsection{A typical procedure for three-component condensation reaction of benzaldehyde, dimedone and ammonium acetate}

In a small test tube, a mixture of benzaldehyde $(0.106 \mathrm{~g}, 1 \mathrm{mmol})$, dimedone $(0.280 \mathrm{~g}, 2 \mathrm{mmol})$ and $\mathrm{NH}_{4} \mathrm{OAc}$ $(0.115 \mathrm{~g}, 1.5 \mathrm{mmol})$ at room temperature was prepared. The mixture was then irradiated by microwave $(700 \mathrm{~W})$ for $5 \mathrm{~min}$ under solvent and catalyst-free conditions. After completion of the reaction (monitored by TLC, $n$ hexane/ethyl acetate: 4/2), the mixture was cooled to the room temperature and the crude product was recrystallized from hot ethanol to afford the pure 3,3,6,6-tetramethyl-9-phenyl-3,4,6,7,9,10-hexahydro-acridine$1,8(2 H, 5 H)$-dione $\mathbf{4 a}$ in $95 \%$ yield (Table 2 , entry 1 ). 


\section{Conclusions}

In this study, an easy and efficient method for microwave-promoted synthesis of acridinedione materials via the three-component condensation reaction of structurally diverse arylaldehydes $(1 \mathrm{mmol})$, dimedone $(2 \mathrm{mmol})$ and $\mathrm{NH}_{4} \mathrm{OAc}(1.5 \mathrm{mmol})$ was introduced. All reactions were carried out under solvent and catalyst-free conditions under microwave radiation $(700 \mathrm{~W}$ ) giving the products in $81-97 \%$ yields within $3-8 \mathrm{~min}$. The present method represents the significant advantages in terms of short reaction times, high yield of products, easy workup procedure as well as the benefits-deletion of utilizing expensive and hazardous organic solvents and promoters.

\section{Acknowledgements}

The authors gratefully acknowledge the financial support of this work by the research council of Urmia University.

\section{References}

1. Shaabani A., Sarvary A., Ghasemi S., Rezayan A. H., Ghadari R., and Ng S. W. (2011) An environmentally benign approach for the synthesis of bifunctional sulfonamide-amide compounds via isocyanide-based multicomponent reactions. Green Chem., 13, 582-585.

2. Zhu J., and Bienayme H. (2005) Multicomponent Reactions, Wiley VCH, Weinheim.

3. Nasr-Esfahani M., Rafiee Z., and Kashi H. (2016) Nanoparticles tungstophosphoric acid supported on polyamic acid: catalytic synthesis of 1,8-dioxo-decahydroacridines and bulky bis(1,8-dioxodecahydroacridine)s. J. Iran. Chem. Soc., 13, 1449-1461.

4. Tu S., Miao C., Gao Y., Fang F., Zhuang Q., Feng Y., and Shi D. (2004) A novel cascade reaction of aryl aldoxime with dimedone under microwave irradiation: the synthesis of $N$-hydroxylacridine. Synlett, 255-258.

5. Ngadi L., Galy A. M., Galy J. P., Barbe J., Cremieux A., Chevalier J., and Sharples D. (1990) Some new 1nitro acridine derivatives as antimicrobial agents. Eur. J. Med. Chem., 25, 67-70.

6. Shchekotikhin Y. M., Nikolaeva T. G., Shub G. M., and Kriven'ko A. P. (2001) Synthesis and antimicrobial activity of substituted 1,8-dioxodecahydroacridines. Pharm. Chem. J., 35, 206-208.

7. Pyrko A. N. (2008) Synthesis and transformations of new 1,2,3,4,5,6,7,8,9,10-decahydroacridine-1,8-dione derivatives. Russ. J. Org. Chem., 44, 1215-1224.

8. Wainwright M. J. (2001) Acridine-a neglected antibacterial chromophore. J. Antimicrob. Chemother., 47, 113.

9. Palani K., Thirumalai D., Ambalavanan P., Ponnuswamy M. N., and Ramakrishnan V. T. (2005) Synthesis and characterization of 9-(4-nitrophenyl)-3,3,6,6-tetramethyl-3,4,6,7,9,10-hexahydro-1,8(2H,5H) acridinedione and its methoxyphenyl derivative. J. Chem. Crystallogr., 35, 751-760.

10. Tu S., Zhang X., Shi F., Li T., Wang Q., Zhu X., Zhang J., and Xu J. (2005) One-pot synthesis of novel $N$ cyclo-propyldecahydroacridine-1,8-dione derivatives under microwave irradiation. J. Heterocycl. Chem., 42, 1155-1159.

11. Gamage S. A., Spicer J. A., Atwell G. J., Finlay G. J., Baguley B. C., and Denny W. A. (1999) Structureactivity relationships for substituted bis(acridine-4-carboxamides): a new class of anticancer agents. J. Med. Chem., 42, 2383-2393.

12. Kaya M., Basar E., Çakir E., Tunca E., and Bulbul M. (2012) Synthesis and characterization of novel dioxoacridine sulfonamide derivatives as new carbonic anhydrase inhibitors. J. Enzym. Inhib. Med. Chem., 27, 509-514.

13. Palani K., Ambalavanan P., Ponnuswamy M. N., Murugan P., and Ramakrishnan V. T. (2005) Crystal structures of two acridinedione derivatives. Cryst. Res. Technol., 40, 277-282.

14. Kidwai M., and Bhatnagar D. (2010) Ceric ammonium nitrate (CAN) catalyzed synthesis of $N$-substituted decahydroacridine-1,8-diones in PEG. Tetrahedron Lett., 51, 2700-2703.

15. Kawase M., Shah A., Gaveriya H., Motohashi N., Sakagami H., Varga A., and Molnar J. (2002) 3,5Dibenzoyl-1,4-dihydropyridines: synthesis and MDR reversal in tumor cells. Bioorg. Med. Chem., 10, 10511055.

16. Janis R. A., and Triggle D. J. (1983) New developments in calcium ion channel antagonists. J. Med. Chem., 26, 775-785.

17. Ulus R., Yeşildağ I., Tanç M., Bülbül M., Kaya M., and Supuran C. T. (2013) Synthesis of novel acridine and bis acridine sulfonamides with effective inhibitory activity against the cytosolic carbonic anhydrase isoforms II and VII. Bioorg. Med. Chem., 21, 5799-5805. 
18. Mikata Y., Yokoyama M., Mogami K., Kato M., Okura I., Chikira M., and Yano S. (1998) Intercalatorlinked cisplatin: synthesis and antitumor activity of cis-dichloroplatinum(II) complexes connected to acridine and phenylquinolines by one methylene chain. Inorg. Chim. Acta., 279, 51-57.

19. da Rocha Pitta M. G., Souza É. S., Barros F. W. A., Filho M. O. M., Pessoa C. O., Hernandes M. Z., do Carmo Alves de Lima M., Galdino S. L., and da Rocha Pitta I. (2013) Synthesis and in vitro anticancer activity of novel thiazacridine derivatives. Med. Chem. Res., 22, 2421-2429.

20. Tu S. J., Lu Z., Shi D., Yao C., Gao Y., and Guo C. (2002) A convenient synthesis of 9-aryl-3,3,6,6-tetramethyl-1,2,3,4,5,6,7,8,9,10-decahydroacridine-1,8-diones under microwave irradiation without solvent. Synth. Commun., 32, 2181-2185.

21. Wang G. W., and Miao C. B. (2006) Environmentally benign one-pot multi-component approaches to the synthesis of novel unsymmetrical 4-arylacridinediones. Green Chem., 8, 1080-1085.

22. Das B., Thirupathi P., Mahender I., Reddy V. S., and Rao Y. K. (2006) Amberlyst-15: an efficient reusable heterogeneous catalyst for the synthesis of 1,8-dioxo-octahydroxanthenes and 1,8-dioxo-decahydroacridines. J. Mol. Catal. A: Chem., 247, 233-239.

23. Xia J. J., and Zhang K. H. (2012) Synthesis of N-substituted acridinediones and polyhydroquinoline derivatives in refluxing water. Molecules, 17, 5339-5345.

24. Hong M., and Xiao G. (2012) FSG-Hf $\left(\mathrm{NPf}_{2}\right)_{4}$ catalyzed, environmentally benign synthesis of 1,8-dioxodeca-hydroaridines in water-ethanol. J. Fluorine Chem., 144, 7-9.

25. Zareia Z., and Akhlaghinia B. (2017) ZnII doped and immobilized on functionalized magnetic hydrotalcite $\left(\mathrm{Fe}_{3} \mathrm{O}_{4} / \mathrm{HT}-\mathrm{SMTU}-\mathrm{Zn}^{\mathrm{II}}\right)$ : a novel, green and magnetically recyclable bifunctional nanocatalyst for the onepot multi-component synthesis of acridinediones under solvent-free conditions. New J. Chem., 41, 1548515500.

26. Işık A., Aday B., Ulus R., and Kaya M. (2015) One-pot, facile, highly efficient, and green synthesis of acridinedione derivatives using vitamin $\mathrm{B}_{1}$. Synth. Commun., 45, 2823-2831.

27. Rezaei R., Khalifeh R., Rajabzadeh M., Dorosty L., and Doroodmand M. M. (2013) Melamine-formaldehyde resin supported $\mathrm{H}^{+}$-catalyzed three-component synthesis of 1,8-dioxodecahydroacridine derivatives in water and under solvent-free conditions. Heterocycl. Commun., 19, 57-63.

28. Pamuk H., Aday B., Şen F., and Kaya M. (2015) PtNPs@GO as a highly efficient and reusable catalyst for one-pot synthesis of acridinedione derivatives. RSC Adv., 5, 49295-49300.

29. Mahesh P., Guruswamy K., Diwakar B. S., Devi B. R., Murthy Y. L. N., Kollu P., and Pammi S. V. N. (2015) Magnetically separable recyclable nano-ferrite catalyst for the synthesis of acridinediones and their derivatives under solvent-free conditions. Chem. Lett., 44, 1386-1388.

30. Khojastehnezhad A., Rahimizadeh M., Eshghi H., Moeinpour F., and Bakavoli M. (2014) Ferric hydrogen sulfate supported on silica-coated nickel ferrite nanoparticles as new and green magnetically separable catalyst for 1,8-dioxodecahydroacridine synthesis. Chinese J. Catal., 35, 376-382.

31. Aday B., Pamuk H., Kaya M., and Sen F. (2016) Graphene oxide as highly effective and readily recyclable catalyst using for the one-pot synthesis of 1,8-dioxoacridine derivatives. J. Nanosci. Nanotechnol., 16, 64986504.

32. Ramesh K. B., and Pasha M. A. (2014) Study on one-pot four-component synthesis of 9-aryl-hexahydroacridine-1,8-diones using $\mathrm{SiO}_{2}-\mathrm{I}$ as a new heterogeneous catalyst and their anticancer activity. Bioorg. Med. Chem. Lett., 24, 3907-3913.

33. Nikpassand M., Mamaghani M., and Tabatabaeian K. (2009) An efficient one-pot three-component synthesis of fused 1,4-dihydropyridines using HY-zeolit. Molecules, 14, 1468-1474.

34. Vahdat S. M., and Baghery S. (2012) An efficient one-pot synthesis of 1,8-dioxodecahydroacridine by indium (III) chloride under ambient temperature in ethanol. Heterocycl. Lett., 2, 43-51.

35. Rostamizadeh S., Amirahmadi A., Shadjou N., and Amani A. M. (2012) MCM-41-SO $\mathrm{SO}_{3} \mathrm{H}$ as a nanoreactor for the one-pot, solvent-free synthesis of 1,8-dioxo-9-aryl decahydroacridines. J. Heterocycl. Chem., 49, 111-115.

36. Zhu A., Liu R., and Du C., Li L. (2017) Betainium-based ionic liquids catalyzed multicomponent Hantzsch reactions for the efficient synthesis of acridinediones. RSC Adv., 7, 6679-6684.

37. Yü S. J., Wu S., Zhao X. M., and Lü C. W. (2017) Green and efficient synthesis of acridine-1,8-diones and hexahydroquinolines via a $\mathrm{KH}_{2} \mathrm{PO}_{4}$ catalyzed Hantzsch-type reaction in aqueous ethanol. Res. Chem. Intermed., 43, 3121-3130.

38. Kiani M., and Mohammadipour M. (2017) $\mathrm{Fe}_{3} \mathrm{O}_{4} @ \mathrm{SiO}_{2}-\mathrm{MoO}_{3} \mathrm{H}$ nanoparticles: a magnetically recyclable nanocatalyst system for the synthesis of 1,8-dioxodecahydroacridine derivatives. RSC Adv., 7, 997-1007. 
39. Murthy Y. L. N., Rajack A., Ramji M. T., Babu J. J., Praveen C., and Lakshmi K. A. (2012) Design, solvent free synthesis, and antimicrobial evaluation of 1,4-dihydropyridines. Bioorg. Med. Chem. Lett., 22, 60166023.

40. Shen Y. B., and Wang G. W. (2008) Solvent-free synthesis of xanthenediones and acridinediones, ARKIVOC, $x v i, 1-8$.

41. Patil D., Chandam D., Mulik A., Patil P., Jagadale S., Kant R., Gupta V., and Deshmukh M. (2014) Novel Brønsted acidic ionic liquid ([CMIM] $\left[\mathrm{CF}_{3} \mathrm{COO}\right]$ ) prompted multicomponent Hantzsch reaction for the ecofriendly synthesis of acridinediones: an efficient and recyclable catalyst. Catal. Lett., 144, 949-958.

42. Di'az-Ortiz A., Prieto P., and de la Hoz A. (2019) A critical overview on the effect of microwave irradiation in organic synthesis. Chem. Rec., 19, 85-97.

43. Stefanidis G., and Stankiewicz A. (2016) Alternative Energy Sources for Green Chemistry, $1^{\text {st }}$ ed., Royal Society of Chemistry, Cambridge, UK.

44. Horikoshi S., and Serpone N. (2014) Role of microwaves in heterogeneous catalytic systems. Catal. Sci. Technol., 4, 1197-1210.

45. de la Hoz A., and Loupy A. (2013) Microwaves in Organic Synthesis, $3^{\text {rd }}$ ed., Wiley-VCH, Weinheim.

46. Polshettiwar V., Nadagouda M. N., and Varma R. S. (2009) Microwave-assisted chemistry: a rapid and sustainable route to synthesis of organics and nanomaterials. Aust. J. Chem., 62, 16-26.

47. Polshettiwar V., and Varma R. S. (2008) Microwave-assisted organic synthesis and transformations using benign reaction media. Acc. Chem. Res., 41, 629-639.

48. Tierney J. P., and Lidström P. (2007) Microwave Assisted Organic Synthesis, Blackwell Publishing, Oxford, UK.

49. de la Hoz A., D1'az-Ortiz A., and Moreno A. (2005) Microwaves in organic synthesis. Thermal and nonthermal microwave effects. Chem. Soc. Rev., 34, 164-178.

50. Kulkarni A. S., and Jayaram R. V. (2004) Liquid phase catalytic transfer hydrogenation of aromatic nitro compounds on $\mathrm{La}_{1-\mathrm{x}} \mathrm{Sr}_{x} \mathrm{FeO}_{3}$ perovskites prepared by microwave irradiation. J. Mol. Catal. A: Chem., 223, 107-110.

51. Bogdal, D. (2005) Microwave-assisted Organic Synthesis, One Hundred Reaction Procedures, $1^{\text {st }}$ ed., Elsevier Science.

52. Lidström P., Tierney J., Wathey B., and Westman J. (2001) Microwave assisted organic synthesis - a review. Tetrahedron, 57, 9225-9283.

53. Vanden Eynde J. J., and Mayence A. (2003) Synthesis and aromatization of Hantzsch 1,4-dihydropyridines under microwave irradiation. An overview. Molecules, 8, 381-391.

54. Cotterill I. C., Usyatinsky A. Y., Arnold J. M., Clark D. S., Dordick J. S., Michels P. C., and Khmelnitsky Y. L. (1998) Microwave assisted combinatorial chemistry, synthesis of substituted pyridines. Tetrahedron Lett., 39, 1117-1120.

55. Vanden Eynde J. J., Labuche N., and van Haverbeke Y. (1997) Microwave-mediated domino reaction in dry medium. Preparation of dihydropyridinones and pyridinones structurally related to Hantzsch esters. Synth. Commun., 27, 3683-3690.

56. He W., Fang Z., Zhang K., Tu T., Lv N., Qiu C., and Guo K. (2018) A novel micro-flow system under microwave irradiation for continuous synthesis of 1,4-dihydropyridines in the absence of solvents via Hantzsch reaction. Chem. Eng. J., 331, 161-168.

57. Sharma D., Bandna Reddy C. B., Kumar S., Shil A. K., Guha N. R., and Das P. (2013) Microwave assisted solvent and catalyst free method for novel classes of $\beta$-enaminoester and acridinedione synthesis. RSC Adv., 3, 10335-10340.

58. Gilanizadeh M., and Zeynizadeh B. (2019) Synthesis of acridinediones and biscoumarins using $\mathrm{Fe}_{3} \mathrm{O}_{4} @ \mathrm{SiO}_{2} @ \mathrm{Ni}-\mathrm{Zn}-\mathrm{Fe}$ LDH as an efficient magnetically recoverable mesoporous catalyst. Polycycl. Aromat. Compd., doi: 10.1080/10406638.2019.1567560.

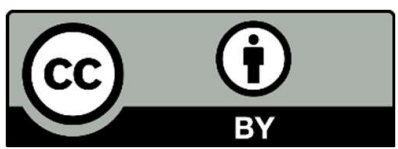

(C) 2020 by the authors; licensee Growing Science, Canada. This is an open access article distributed under the terms and conditions of the Creative Commons Attribution (CC-BY) license (http://creativecommons.org/licenses/by/4.0/). 